\title{
AS FORMAS DA MEMÓRIA EM PONCIÁ VICÊNCIO, DE CONCEIÇÃO EVARISTO
}

\section{THE FORMS OF MEMORY IN PONCIÁ VICÊNCIO, BY CONCEIÇÃO EVARISTO}

\author{
Fabrício Lemos da Costa*
}

Resumo: O presente artigo tem como objetivo refletir sobre as formas da memória em Ponciá Vicêncio (2003), de Conceição Evaristo. Trata-se de uma abordagem que considera o romance da escritora brasileira como amálgama da presença da memória coletiva, num elo que liga o passado e o presente, para, enfim, projetar-se num futuro comum. Com isso, a escritura se revela, por sua vez, como matéria de resistência, marca de tantos escritos contemporâneos na literatura brasileira, em que a figura do "subalterno" se coloca como sujeito que fala por si, rompendo o silenciar histórico, assim como pensamentos colonizadores e racistas. Para este trabalho, recorremos às reflexões de Evaristo (2009), Barossi (2017), Oliveira (2019), Silva (2010), Pereira (2016), Schøllhammer (2009), Spivak (2010) e Foucault $(1999,2002)$.

Palavras-chave: Ponciá Vicêncio, Conceição Evaristo, Memória, Resistência.

Abstract: This article aims to reflect on the forms of memory in Ponciá Vicêncio (2003), by Conceição Evaristo. It is about an approach that considers the novel by the Brazilian writer as an amalgam of the presence of collective memory, in a link that connects the past and the present, for, finally, project itself into a common future. With this, the writing is revealed, in its turn, as a matter of resistance, a mark of so many contemporary writings in Brazilian literature, in which the figure of the "subaltern" stands as a subject that speaks for itself, breaking the historical silence, as well as colonizing and racist thoughts. For this work, we use the reflections of Evaristo (2009), Barossi (2017), Oliveira (2019), Silva (2010), Pereira (2016), Schøllhammer (2009), Spivak (2010) and Foucault (1999, 2002).

KeYwords: Ponciá Vicêncio, Conceição Evaristo, Memory, Resistence.

\footnotetext{
"Mestre em Estudos Literários (PPGL/UFPA, 2020), Doutorando em Estudos Literários (PPGL/UFPA). E-mail: fabricio. lemos1987@yahoo.com.br.
} 
Compreendera que sua vida, um grão de areia lá no fundo do rio, só tomaria corpo, só engrandeceria, se se tornasse matéria argamassa de outras vidas. Descobria também que não bastava saber ler e assinar o nome. Da leitura era preciso tirar outra sabedoria. (Ponciá Vicêncio, Conceição Evaristo) ${ }^{1}$

O romance que vamos analisar, neste trabalho, intitulado Ponciá Vicêncio, da escritora brasileira Conceição Evaristo, ${ }^{2}$ foi publicado pela primeira vez em 2003, pela Mazza Edições. Trata-se do primeiro romance da autora, em que temáticas em torno da memória comum do povo negro se perfazem como amálgama da trama, cuja ancestralidade, sabedoria e aprendizados são clave para reflexões e possíveis resistências quando da identificação com o passado ancestral. Na narrativa, corpus de nosso estudo, conta-se a história da personagem Ponciá Vicêncio, que dá título ao livro. Nesta figura feminina, coaduna-se - da infância à vida adulta - toda uma coletividade, participando de forças que representam a presença ainda viva de todo um povo ancestral, chegado de várias regiões de África no Brasil, para servir ao sistema escravocrata. No romance, portanto, ficamos conhecendo a trajetória feminina de Ponciá, naquilo que chamaremos de "sempre retorno" às origens. Vejamos um trecho inicial da narrativa:

Quando Ponciá Vicêncio viu o arco-íris no céu, sentiu um calafrio. Recordou o medo que tivera durante toda a sua infância. Diziam que menina que passasse por debaixo do arco-íris virava menino. Ela ia buscar o barro na beira do rio e lá estava a cobra celeste bebendo água. Como passar para o outro lado? Às vezes, ficava horas e horas na beira do rio esperando a colorida cobra do ar desaparecer. Qual nada! O arco-íris era teimoso! Dava uma aflição danada. Sabia que a mãe estava esperando por ela. Juntava, então, as saias entre as pernas tampando os sexos e, num pulo, com o coração aos saltos, passava por debaixo do angorô. Depois se apalpava toda. Lá estavam os seinhos, que começavam a crescer. Lá estava o púbis bem plano, sem nenhuma saliência a não ser os pelos. Ponciá sentia um alívio imenso. Continuava menina. Passara rápido, de um só pulo. Conseguira enganar o arco e não virara menino. (EVARISTO, 2003, p. 9)

Neste longo fragmento, temos configurado, à guisa de início de nossa reflexão, a perspectiva que pretendemos analisar ao longo da obra, qual seja, a memória ancestral se articulando como matéria ficcional na narrativa, em que se coloca como vivência da personagem, ao fazer parte, portanto, de sua existência e crença cotidiana. Na passagem, é a memória viva

${ }^{1}$ EVARISTO, 2003, p. 131.

${ }^{2}$ Cf. PEREIRA, 2016, p. 35: "Maria da Conceição Evaristo de Brito é mineira, natural de Belo Horizonte, nascida em 29 de novembro de 1946. Na década de 1970, mudou-se para o Rio de Janeiro em busca de formação acadêmica e melhores condições de trabalho. Graduou-se em Letras pela Universidade Federal do Rio de Janeiro (UFRJ) e trabalhou como professora da rede pública de ensino da capital fluminense. Mestre em literatura brasileira pela Pontifícia Universidade Católica do Rio de Janeiro (PUC-Rio), hoje é doutora em literatura comparada pela Universidade Federal Fluminense (UFF)." 
e presente que faz Ponciá Vicêncio esperar o tempo do arco-íris, a cobra celeste, ou ainda, o angorô, a divindade andrógina que liga, de acordo com a mitologia bantu, o céu e a terra. Vê-se que esta memória faz Ponciá esperar para atravessar, com receio de tornar-se menino, dado a força da androginia de angorô. No trecho, infere-se também o ofício que liga as mulheres daquela família - o trabalho com o barro.

Com a menção ao barro buscado no rio, gostaríamos de projetar o nosso estudo. Com ele, dá-se forma, desenham-se figuras, imagens, rostos, corpos, vasilhas para guardar memórias. Neste ínterim, com esta matéria-prima, manuseada pelas mãos das mulheres, o passado continua vivo no presente. Assim, com ela, articulam-se contornos e formas, inscrevendo-se a lembrança do passado comum. Poder-se-ia dizer, para efeito de interpretação, que a argila trabalhada pelas mãos femininas, desenha a visão da mulher em relação aos acontecimentos naquela família, assim como pode significar, agora, no plano da textualidade, uma metáfora do inscrever a própria história. Desenvolveremos ainda este aspecto.

No que tange à história escrita pelo próprio negro, sujeito da enunciação na literatura contemporânea brasileira, vale a pena recorrermos ao argumento da escritora Conceição Evaristo (2009) em um ensaio intitulado Literatura negra: uma poética de nossa afro-brasilidade. Para ela:

Pode-se dizer que um sentimento positivo de etnicidade atravessa a textualidade afro-brasileira. Personagens são descritos sem a intenção de esconder uma identidade negra e, muitas vezes, são apresentados a partir de uma valorização da pele, dos traços físicos, das heranças culturais oriundas de povos africanos e da inserção/exclusão que os afrodescendentes sofrem na sociedade brasileira. Esses processos de construção de personagens e enredos destoam dos modos estereotipados ou da invisibilidade com que negros e mestiços são tratados pela literatura brasileira em geral. (EVARISTO, 2009, p. 19-20)

Com esta citação, podemos pensar o lugar do negro como personagem na ficção brasileira, desde a sua formação. Para esta figura, como nos faz pensar Evaristo, de alguma maneira, fruto que é do racismo, este sempre foi tratado sob o viés da "sexualidade" e da "malandragem". Em suma, é o "desavergonhado", tantas vezes representado em diversos textos da literatura nacional. Todavia, na contemporaneidade, reclama-se o outro lugar - a revisitação da história. Este passa a exigir o lugar da escritura, como sujeito da enunciação, não mais como mero representado pelo "olhar" do artista branco. No que diz respeito à noção de contemporaneidade, faz-se mister problematizarmos, em parte, este termo para que possamos melhor vislumbrar o objeto de nosso estudo. Para isto, é interessante o que diz Karl Erik Schøllhammer (2009) em Ficção brasileira contemporânea. Ao pensar alguns textos da literatura contemporânea, segundo o estudioso, revela-se, atualmente, "um fascínio em torno de "vozes marginais", de 
uma realidade ${ }^{3}$ excluída, que agora exige seu espaço também na ficção" (SCHØLLHAMMER, 2009, p. 98-99).

No que tange ao corpus de nosso estudo, esta voz "marginal", termo utilizado por Schøllhammer (2009), dá-se numa dupla camada. No plano da autoria, trata-se de uma mulher negra, que, a exemplo da escritora Carolina de Jesus, pontua o direito à escrita. No outro viés, seus personagens, em sua maioria, são mulheres também negras e excluídas socialmente. Sob este ponto, portanto, é imprescindível que situemos a ficção de Conceição Evaristo como literatura de nosso tempo, que, ao inscrever a sua "voz", encaminha a escritura para sujeitos das margens. Neles, como é recorrente na ficção contemporânea, temos "uma linguagem em texto e imagem que incorpora a crueza da realidade periférica” (SCHØLLHAMMER, 2009, p. 100). Sob esta perspectiva, é a realidade social e suas problemáticas, que serve de matéria em vários textos da escritora, sobretudo sob a perspectiva da personagem feminina. Dito isto, para melhor entendimento da obra, faremos um breve resumo do romance Ponciá Vicêncio.

A narrativa conta a trajetória da personagem Ponciá Vicêncio, que vive com sua mãe, cujo nome é Maria Vicêncio, na Vila Vicêncio, nome do antigo coronel, do qual a família de Ponciá carrega o nome do antigo proprietário de escravos. No tocante à história familiar, lembramos que o avô da personagem fora escravo e, como maneira de resistir à escravidão, matou sua esposa, para, em seguida, tirar a própria vida. Em relação a este último intento, não conseguiu efetivar o plano, deixando apenas um braço "cotó", entretanto, após a sua morte, este fato se mostrou sempre muito vivo na memória dos parentes.

A família é constituída ainda pelo pai de Ponciá e o irmão, cujo nome é Luandi Vicêncio. Ambos trabalhavam na lavoura dos brancos. Quando da morte inesperada do pai, Ponciá tenta a vida na cidade, afastando-se da família, ao passo que o irmão faz o mesmo e passa a trabalhar numa delegacia, como empregado encarregado da limpeza. Lá, ele conhece o soldado negro Nestor, ficando amigos. Este último leva Luandi a casas de prostituição, na zona, e o irmão de Ponciá conhece e se apaixona por uma prostituta chamada Bilisa, que, ao final, mesmo com planos de casamento com Luandi, é assassinada pelo cafetão Climério, quando esta resolve sair da prostituição.

Um dado importante para o entendimento da obra é que a narrativa se dá em forma de flashbacks. Neste ir e voltar, Ponciá, já moradora de uma barraca na favela, empregada doméstica e casada com um pedreiro, relembra a vida da infância, mesmo quando era criança de colo, cujo estranho comportamento de imitar o avô que tinha um braço "cotó", estranhava a todos. Outro fato interessante, que, a nosso ver, conduz a história como amálgama da lembrança diz respeito ao ofício do trabalho com o barro, no qual ela e sua mãe produzem diversos

\footnotetext{
${ }^{3} \mathrm{Na}$ contemporaneidade, esta realidade aparece em sua nua substância, entretanto, este real deve ser compreendido, à guisa da marca desses escritos que chamamos contemporâneos, isto é, como escritura que inscreve a própria voz dos sujeitos marginalizados, assim, eles falam por eles, inserindo as suas visões dos fatos e da história, revisitando-a para redesenhar o seu ponto de vista, feito como sujeitos afetados pelo discurso colonial e racista.
} 
artefatos e objetos. Entre estas produções, encontra-se a imagem de barro representando o avô, miniatura que se faz constante ao longo do enredo.

Ainda para uma melhor compreensão do romance, faz-se necessário enfatizar a presença da negra Nêngua Kainda, uma espécie de velha que carrega as forças ancestrais do povo negro. Nela se revela todo o passado e a memória como sabedoria, sempre conhecedora do futuro daqueles que compõem a família de Ponciá. Assim, neste percurso feminino, Ponciá, moradora da favela, perde sete crianças, nenhuma sobrevive após o nascimento e, neste intercruzar do presente com o passado, faz o caminho do retorno às origens, pedindo o barro que fica no fundo do rio, matéria que modela a memória, dando-lhe forma. Por fim, em um longo período de distância entre mãe, irmão e irmã, estes se reencontram na cidade, após Maria Vicêncio pegar o endereço de Luandi com a velha Nêngua Kainda, deixado por ele mesmo num pedacinho de papel, escrito com a letra do soldado Nestor, numa visita à vila. Ao final, já fardado e formado soldado, Luandi reconhece a irmã na estação, quando esta resolve reencontrar-se com o rio, lugar de memória, onde o arco-íris, a cobra celestial, bebe água.

Feito um resumo do itinerário da personagem e membros da família Vicêncio, gostaríamos de frisar um ponto, que, no nosso entendimento, liga as histórias dos sujeitos na narrativa. Estamos a falar do acesso à escrita e à leitura, aprendidas, em parte, por Ponciá numa breve missão religiosa que chega à comunidade quilombola. Assim, com esta referência à língua escrita, tentaremos desenvolver nossa interpretação, para, enfim, traçarmos o que chamamos, aqui, de "forma da memória como resistência". Vejamos mais um trecho do romance que nos direciona a esta questão:

O saber que se precisa na roça difere em tudo do da cidade. Era melhor deixar a menina aprender a ler. Quem sabe, a estrada da menina seria outra. [...] Quando os padres partiram, depois de terem cumprido todos os seus ofícios, Ponciá logo percebeu que não podia ficar esperando por eles para aumentar o seu saber. Foi avançando sozinha e pertinaz pelas folhas da cartilha. E em poucos meses já sabia ler. (EVARISTO, 2003, p. 25-26)

Questionamo-nos, de acordo com este fragmento, o simbólico que remete à rapidez de uma missão naquela região quilombola. Para efeito de manutenção do poder do branco, interessa um ensinamento completo da escrita e da leitura, isto é, no sentido de abarcar uma complexidade do que significa a leitura crítica do mundo aos sujeitos subalternizados ou bastaria saber escrever o próprio nome e ler pequenas frases, por exemplo? Acreditamos que a limitação é imposta a esta gente, porque a escrita e a leitura do mundo resgatam memórias, divulgando-as aos seus, assim como dá voz ao "subalterno", tornando-o sujeito da enunciação, não mais um mero representado pelo outro, neste caso, o homem branco. Neste sentido, o fenômeno do acesso à língua escrita revela e institui à ideia de pertencimento, de identidade 
ao negro, retirando-lhe da "afasia", como ficou caracterizado na ficção de diversos escritores da literatura brasileira, como sublinha Conceição Evaristo:

Destacando a roupagem estereotípica com a qual os negros são vestidos em várias obras brasileiras, é possível ressaltar um imaginário construído em que o sujeito negro surge destituído do dom da linguagem. Uma afasia, um mutismo, uma impossibilidade de linguagem caracteriza muitas das personagens ficcionais negras, sob pena de muitos autores. (EVARISTO, 2009, p. 22)

Em suma, parece-nos fundamental marcarmos esta particularidade na leitura do romance Ponciá Vicêncio, porque a reflexão sobre a linguagem, isto é, sobre a possibilidade de poder, agora, tornar-se sujeito da enunciação, marca os escritos da literatura contemporânea brasileira. Neste âmbito, a literatura de Evaristo representa com maestria o subalterno negro, periférico e pobre, visto em tantos personagens de sua ficção. Para isso, estes têm direito ao discurso, são articuladores do próprio pensamento. Neste intento, falam dos seus lugares, muitas vezes, da favela, fruto que é da desigualdade social que caracteriza a sociedade brasileira.

Portanto, como argumenta Evaristo (2009, p. 22) essa "negação da linguagem para os personagens negros" é rompida na contemporaneidade, na medida que as personagens são inscritas pelas lentes autorais do sujeito negro, e, no caso de Evaristo, da mulher negra, o que implica, ainda, uma outra "camada" do processo, como comprova uma grande quantidade de personagens femininas em sua literatura. Ainda sob este aspecto, Natalino Oliveira (2019), no artigo Escrever é sangrar: reflexões sobre ancestralidade, racismo e dor em Olhos d'água de Conceição Evaristo, confirma esta questão. Segundo ele:

O povo negro é constituído por uma memória criada e ficcionalizada de forma forçada em uma história oficial forjada. As narrativas oficiais oprimem a realidade dos afrodescendentes. Durante muito tempo e até mesmo nos dias de hoje, os negros têm permanecido como objetos da letra, e não como cidadãos letrados; são prisioneiros de narrativas escritas por outras pessoas e não são apresentadas como protagonistas. (OLIVEIRA, 2019, p.181)

Assim, todos esses aspectos estão implicados como matéria de ficção no romance de Evaristo, podendo-se perceber no questionamento do próprio nome pela personagem, haja vista que Ponciá iniciara seu percurso nas letras, o que a torna, talvez, capaz de pensar criticamente sobre o nome dado. Neste caso, estamos a falar do sobrenome Vicêncio, ligado ao escravocrata Coronel Vicêncio, que a personagem passa a recusar, pois fere, a nosso ver, sua autonomia e identidade: 
Em tempos outros, havia sonhado tanto! Quando mais nova, sonhara até um outro nome para si. Não gostava daquele que lhe deram. Menina, tinha o hábito de ir à beira do rio e lá, se mirando nas águas, gritava o próprio nome: Ponciá Vicêncio! Ponciá Vicêncio! Sentia-se como se estivesse chamando outra pessoa. Não ouvia o seu nome responder dentro de si. Inventava outros. Pandá, Malenga, Quieti, nenhum lhe pertencia também. Ela, inominada, tremendo de medo, temia a brincadeira, mas insistia. A cabeça rodava no vazio, ela vazia se sentia sem nome. Sentiase ninguém. Tinha, então, vontade de choros e risos. (EVARISTO, 2003, p. 16, grifo nosso)

Neste ínterim, entendemos a reflexão de Ponciá sobre o nome dado pelo outro, como marca da escravidão, uma maneira de revisitar a memória do seu povo, naquilo que os une numa só cadeia, a da escravização. Vale ressaltar que todos da comunidade quilombola carregam em seu nome a identificação com o Coronel Vicêncio. Além disso, passado o período da escravidão, muitos negros da região ainda eram explorados na lavoura da família Vicêncio, sob o regime de "liberdade" forjada, ${ }^{4}$ haja vista, que, por exemplo, o pai e o irmão de Ponciá, vivem praticamente todo o tempo nas "terras dos brancos", como é identificada durante a narrativa.

Para isto, recusando o nome, inicialmente, Ponciá resolve ir embora para a cidade, após a morte do pai, para, enfim, tentar desenhar a sua história, longe da memória que lembra a escravidão, o duro serviço da roça. Todavia, ao chegar na cidade, depara-se com novas formas de desigualdade. Torna-se empregada doméstica e passa a morar na favela.

Com isto, sublinhamos que revisitar o passado, prefigurado como lembrança ao longo do romance pela Ponciá - um sempre ir e voltar - configura um interessante artifício de dar forma à memória subjetiva daquela personagem feminina, mas também de todo o seu povo, preso sob o jugo da desigualdade, do racismo e do preconceito, presente e vivo, ainda hoje. Então, na obra, fala-se de uma realidade desigual. Primeiro, a da roça, e seus formatos antigos de subjugar o negro, herdado da escravidão, representado pela lavoura da família Vicêncio, e, segundo, na favela, pela manutenção e extensão do mando do branco em relação ao negro, onde este último é empurrado para a morte em suas mais diversas formas, como a simbólica e a física.

Poder-se-ia, além disso, pensar este aspecto pelas vias de uma reflexão que abarca uma biopolítica. Na esteira de Michel Foucault (1999), podemos pensar os corpos que são

${ }^{4}$ Cf. EVARISTO, 2003, p. 47-48: "Há tempos, quando os negros ganharam aquelas terras, pensaram que estivessem ganhando a verdadeira alforria. Engano. Em muito pouca coisa a situação de antes diferia da do momento. As terras tinham sido ofertas dos antigos donos, que alegavam ser presentes de libertação. E, como tal, podiam ficar por ali, levantar moradias e plantar seus sustentos. Uma condição havia, entretanto, a de que continuassem todos a trabalhar nas terras do Coronel Vicêncio. O coração de muitos se regozijava, iam ser livres, ter moradia fora da fazenda, ter as suas terras e os seus plantios. Para alguns, Coronel Vicêncio parecia um pai, um senhor Deus. O tempo passava e ali estavam os antigos escravos, agora libertos pela 'Lei Áurea', os seus filhos, nascidos do 'Ventre Livre' e os seus netos, que nunca seriam escravos. Sonhando todos sob os efeitos de uma liberdade assinada por uma princesa, fada-madrinha, que do antigo chicote fez uma varinha de condão. Todos; ainda, sob o jugo de um poder que, como Deus, se fazia eterno." 
empurrados facilmente para a morte, em outras palavras, vidas negras que são elimináveis, sem remorso público, pela sociedade racista brasileira. Estamos no terreno, pois, da política no que tange aos poderes, como aponta o pensador francês (1999, p. 127) sobre o direito à vida e à morte, marcas latentes do poder sobre o outro e a si mesmo. Sob este aspecto, podemos afirmar que a personagem Ponciá carrega dentro de si esta consciência sobre o seu corpo e projeta um futuro com possibilidades de mudanças, ou, pelo menos, articula, conscientemente, reflexões sobre a injustiça do seu lugar, pois coexiste, nele, uma permanência de antigas formas de mando e poder do branco privilegiado:

Ponciá Vicêncio deitou-se na cama imunda ao lado do homem e de barriga para cima ficou com o olhar encontrando o nada. Veio-lhe a imagem de porcos no chiqueiro que comem e dormem para serem sacrificados um dia. Seria isto vida, meu Deus? os dias passavam, estava cansada, fraca para viver, mas coragem para morrer, também não tinha ainda. (EVARISTO, 2003, p. 32)

"Para morrer, também não tinha ainda": Este trecho mostra-se revelador para a nossa abordagem. Pois, mesmo consciente de uma política de poder injusta sobre a vida negra, sacrificada pela sociedade desigual, a mulher possui a vontade de saber e crescer como indivíduo autônomo, dona da sua voz, do corpo, enfim, sujeito do próprio discurso, como maneira de pensar mudanças para a própria vida, sendo esta a motivação quando saiu da Vila Vicêncio, como fica claro no trecho seguinte: "Do medo de recuar, do desespero por não querer ficar ali repetindo a história dos seus" (EVARISTO, 2003, p. 38).

Vê-se, assim, que pela lembrança e reflexão, em terceira pessoa, a memória da desigualdade cria uma forma narrativa, é sua matéria ficcional, para, em síntese, articular, no plano da interpretação, a relação entre a "história dos seus", dos afrodescendentes, familiares que são de Ponciá, e a sua real situação, ainda hoje, na favela, na "casa-barraco", na alimentação escassa feita com o marido. Além disso, no que tange ao caso da personagem Ponciá, a situação da desarmonia social abarca outras camadas mais complexas da discriminação.

Para Oliveira (2019), quando se trata das "condições da mulher negra, então, o caso é ainda mais grave. O preconceito contra a mulher negra se manifesta em pelo menos três dimensões: discriminação racial, discriminação de gênero e discriminação de classe social". (OLIVEIRA, 2019, p. 186). Sob esta questão, é fundamental que problematizemos as várias camadas da "subalternidade" ligada à mulher negra e pobre. Spivak (2010), ao falar do "subalterno", e, por sua vez, da "subalternidade", enfatiza esta mulher colocada nesta condição. Segundo ela, "a questão da mulher parece ser mais problemática nesse contexto. Evidentemente, se você é pobre, negra e mulher, está envolvida de três maneiras" (SPIVAK, 2010, p. 85). Destarte, é nesta complexidade que a subalternidade da mulher se desenvolve como condição de total descaso e desigualdade na favela, por exemplo, vivenciadas, muitas vezes, pela violência, como se dá com Ponciá, agredida pelo marido no ambiente doméstico. 
Podemos pontuar este aspecto, utilizando também como exemplo a trajetória de Luandi Vicêncio, irmão de Ponciá. Este, como já relatamos, ao fugir para a cidade, passa a trabalhar como faxineiro da delegacia. Com a ajuda do soldado negro Nestor, ele aprende as letras, conseguindo tornar-se soldado, sonho do rapaz que nasce com a idealização da imagem de Nestor, o qual, para ele, é figura de admiração, pois, trata-se de um negro que podia "mandar" e "prender". Gostaríamos de nos deter nesta vivência de Luandi, porque nos revela as várias camadas do poder no que diz respeito à cor, ao gênero e à posição social. Para isso, vejamos um breve fragmento que serve de estímulo a estas questões:

Luandi não tinha onde passar a noite e depois de caminhar um pouco, resolveu voltar à estação. Poderia assentar ou até deitar em uns dos bancos e esperar o dia seguinte. Foi acordado, entretanto, no meio do sono por um soldado: "O que você está fazendo aqui? Mostre os documentos? O que você faz? Você está armado?” [...] Soldado Nestor pegou Luandi pelo braço e foi levando [...] Luandi se assustou, mas nem raiva teve. Estava feliz. Acabava de fazer uma descoberta. A cidade era mesmo melhor do que na roça. Ali estava a prova. O soldado negro! Ah! que beleza! Na cidade, negro também mandava! (EVARISTO, 2003, p. 70)

Como se vê na passagem, ingenuamente, ou ainda, carente de uma reflexão crítica quando da chegada na cidade, o rapaz idealiza aquele lugar como da ordem de uma mudança quando compara à roça. Assim, após a prisão, o delegado branco e o soldado negro Nestor descobrem tratar-se um rapaz ingênuo, recém chegado da zona rural. O delegado oferece-lhe um emprego de faxineiro, ao passo que este aceita, na crença de poder formar-se soldado, caso aprendesse a ler e a escrever. Em suma, "subir" de cargo implica adquirir o poder da linguagem em sua modalidade escrita: "Se ele estudasse muito, poderia ser soldado um dia. Poderia ser mais, muito mais. Entretanto, Luandi só queria ser soldado. Queria mandar. Prender. Bater. Queria ter a voz alta e forte como a dos brancos" (EVARISTO, 2003, p. 71).

Desse modo, vemos que Luandi, diferentemente de Ponciá, ao aprender as letras, ensinadas por Nestor, torna-se soldado, como ficamos sabendo quase ao final do romance. Com isto, percebe-se uma larga diferença quando lembramos a trajetória de Ponciá. Esta se torna empregada doméstica ao chegar na cidade, mesmo sabendo ler e escrever, aprendidas, inicialmente, nas primeiras missões religiosas no quilombo, e, depois, melhoradas pela sua vontade de saber. Neste ínterim, suas oportunidades, fruto de uma desigualdade de gênero, são muito mais escassas, quando colocadas a par da comparação com o irmão. Na ficção de Conceição Evaristo, estes exemplos da discriminação de gênero estão presentes em diversas personagens femininas, como se dá na história de várias mulheres no livro de contos intitulado Insubmissas lágrimas de mulheres, publicado pela primeira vez em 2011, pela editora Nandyala.

Voltando-nos ao viés que inaugura uma espécie de "poder" quando do acesso à escrita, como fica claro no itinerário de Luandi e Nestor, ambos soldados negros, que podem prender, 
bater e ter voz na cidade, como pensou o irmão de Ponciá, uma outra voz precisa ser delineada neste percurso. Estamos a falar da negra Nêngua Kainda, mulher ancestral, que carrega e comunga de sabedorias antigas. Com ela, quase em voz de coro do povo negro, poder-se-ia indagar se é suficiente apenas saber ler e escrever, ou ainda, quando do acesso à estas modalidades da linguagem culta, ao serem usadas, como torná-las "armas" contra o preconceito racial, em favor dos seus? Vejamos um trecho:

Nêngua Kainda olhou os trajes de Luandi e deu de rir, mas com os olhos. Ria dizendo que o moço estava num caminho que não era o dele. Que estava querendo ter voz de mando, mas de que valeria mandar tanto, se sozinho? Se a voz de Luandi não fosse o eco encompridado de outras vozes-irmãs sofridas, a fala dele nem no deserto cairia. Poderia, sim, ser peia, areia nos olhos dele, chicote que ele levantaria contra os corpos dos seus. (EVARISTO, 2003, p. 96)

Com este comentário de Nêngua Kainda, chegamos à clave de nossa reflexão. E com ele, indagamo-nos: como dar forma à resistência contra os "chicotes" modernos da escravidão e os novos navios negreiros, compactados em camburões da polícia? Em parte, respondemos: dando forma à memória, não esquecendo as dores antigas da escravidão, fazendo-as ainda viva como maneira de resistir ao racismo de hoje, para, enfim, "gritar" coletivamente. Desta forma, consideramos o corpus de nosso estudo um exemplo do que chamamos de "forma" da memória, pois, nele, se configura a matéria ficcional que mostra uma realidade racista atual, ligada, por sua vez, à história da escravização no Brasil.

Entende-se, assim, ser necessário realizar o "caminho de volta”, revisitar a história, a memória, para fazer vir à tona uma "nova história", redesenhada pelo próprio negro, quando se torna sujeito da enunciação. É o que faz Ponciá Vicêncio quando sai em busca do barro e do rio, metáfora do manusear e modelar a própria imagem e figura, com as "lentes" da subjetividade e da vivência, caminho que é da "escrevivência”, termo criado pela própria escritora Conceição Evaristo.

No bojo da narrativa, reclama-se uma voz coletiva, caso contrário, o "chicote” pode ser erguido contra "os corpos dos seus", como alerta Nêngua Kainda. Para isto, faz-se mister dar forma a um discurso que "contesta a história brasileira que prima em ignorar eventos relativos à trajetória dos africanos e seus descendentes no Brasil" (EVARISTO, 2009, p. 24). Podemos afirmar, num diálogo com os argumentos de Evaristo, que este "trajeto" pode se confirmar também num retorno à memória ancestral, à religiosidade, mitos e crenças do povo negro, presentes, como é sabido, em vários aspectos da vida cultural brasileira. Com elas, assim, é possível resistir, marcar a presença como identidade.

Para tanto, faz-se necessário que o "subalterno", para usarmos um termo de Spivak (2010), tenha a consciência que o poder apenas individual, como temos no caso de Nestor e 
Luandi, que prendem outros negros, torna-se falha quando concentrada em poucos sujeitos. No fundo, uma realidade logo se revela a estes indivíduos. Queremos dizer com isto que, quase sempre, acima do sujeito claramente subalternizado, mas que, por uma falsa percepção e reflexão, acha que possui o poder, no entanto, percebe, em algum momento, por meio de alguma oportunidade repentina, que há sempre "delegados brancos" como chefes, no que diz respeito à hierarquia, por exemplo, como se dá na narrativa de Evaristo. Trata-se, portanto, de um falso poder. Então, quando não realizado em "aliança” com os seus, um chicote encontrar-se-á sempre erguido para os semelhantes, como uma arma apontada para si mesmo.

Neste sentido, para dar forma à resistência, deixando-se o "subalterno" falar por si, é fundamental realizar o "caminho de volta", onde estão, em conjunto, todos, porque, neste retorno à memória, todo negro brasileiro tem uma origem comum, qual seja, a da barbárie pela escravização. Assim, para deixar de ser "silencioso e silenciado" (SPIVAK, 2010, p. 54), é fundamental e urgente a "solidariedade através de uma política de alianças" (SPIVAK, 2010, p. 54). Na narrativa, a aliança realizada entre Nestor e Luandi fez deste último um soldado, todavia, anterior a este fato, Nestor se esquivava do amigo quando da presença de um branco.

Da mesma maneira, ambos são silenciados em sua memória coletiva pelo ataque discursivo do delegado, em relação aos negros em geral. Estes se calam, ficam mudos: "E que Luandi não levasse a mal o que ele ia dizer, mas quase todo negro era vagabundo, baderneiro, ladrão e com propensão ao crime. Poucos, muito poucos, eram como o Soldado Nestor e ele" (EVARISTO, 2003, p. 121). Vê-se que este discurso racista do delegado tem um único objetivo: fazer romper a possibilidade da solidariedade, das alianças, e, se houver, que seja apenas entre limitados indivíduos, como Nestor e Luandi, nunca da coletividade. Sob este efeito, Nestor parecia estar, em parte, incorporado a este discurso do delegado, justificado, talvez, pois "vivia longe do seu clã" (EVARISTO, 2003, p. 113).

Com isto, de acordo com a análise do romance, não basta o acesso ao mundo da escrita, pois sem revisitar a história pelas lentes do "subalterno", em algum momento, "o circuito marcado por essa violência epistêmica”, como afirma Spivak (2010, p. 54) em relação ao subalterno, apontará a arma para "os seus". Em nossa visão, o subalterno poderá falar, quando ecoar em coro o pensamento de Nêngua Kainda, e, neste momento, todos serão uma única voz, podendo voltar à história do seu povo.

Em síntese, quando lembramos, no início da narrativa, que os negros da Vila Vicêncio continuam a trabalhar na "Terra dos brancos", diz muito sobre a manutenção do pensamento colonial na sociedade brasileira pós-período escravocrata. Além disso, quando direcionamos nosso olhar para a cidade em Ponciá Vicêncio, vê-se, a seu modo, a mesma configuração da exploração. Neste ínterim, é imprescindível atentarmos ao esforço de vários escritores e intelectuais, a exemplo de Conceição Evaristo na ficção, e mesmo em seus estudos mais acadêmicos, no sentido de dar forma a discursos que tentam revisitar a história brasileira colonial escravocrata, para, enfim, desmontar com a ideia de uma história única e verdadeira - a do 
branco. Com isto, pensa-se, no plano da reflexão, o desfazer de "violências epistêmicas", como sublinha Spivak (2010).

Neste bojo, pensar criticamente estas "violências", implica a possibilidade de redesenhar a história e a memória de sujeitos silenciados quando da instauração desta suposta "verdade histórica" do vencedor e colonizador branco europeu, dono que foi de corpos e vidas no período das violentas conquistas. Por outro lado, neste momento da literatura contemporânea, como temos afirmado em nosso estudo, o qual nosso corpus de análise é um exemplo, encontramos o sujeito subalterno falando por si, no fundo, nestes escritos, deparamos com aqueles sujeitos evidenciados por Spivak (2010) em seu livro Pode um subalterno falar?, sendo "homens e mulheres entre os camponeses iletrados, os tribais, os estratos mais baixos do subproletariado urbano" (SPIVAK, 2010, p. 54).

No romance, temos um exemplo interessante deste apagamento do outro, e, ao mesmo tempo, do sujeito discriminado socialmente falando por si. Este fato, dá-se na passagem em que o Soldado Nestor convida Luandi para ver uma exposição. Neste momento, sem conhecimento de Ponciá Vicêncio e sua mãe, seus trabalhos com o barro são expostos numa galeria de arte na cidade, identificados com seus nomes. Entretanto, na mesma sala de exposição, há trabalhos de outros indivíduos sem nome, identificados apenas com o dono do objeto - Um coronel. Vejamos:

Soldado Nestor assim leu: "Autor desconhecido", Região: Município do Engenho Cruzado, Proprietário: Coronel José Maria da Cruz. E com olhar inebriado com tudo o que via, Luandi se encontrava e se perdia em meio aos trabalhos da exposição [...] E, sem que Luandi pedisse, o amigo, também emocionado, pegou o cartãozinho branco que estava ao lado dos objetos e leu: "Autores: Maria Vicêncio e filha Ponciá Vicêncio", Região: Vila Vicêncio, Proprietário: Dr. Aristeu Pena Forte Soares Vicêncio. Luandi olhava os trabalhos da mãe e da irmã como se visse pela primeira vez, embora se reconhecesse em cada um deles. Observava as minúcias de tudo. Havia os objetos de uso: panelas, potes, bilhas, jarros e os de enfeites, em tamanho menor, pequeníssimos. Pessoas, animais, utensílios de casa, tudo coisas de faz-de-conta, objetos de enfeitar, de brincar. Criações feitas, como se as duas quisessem miniaturar a vida, para que ela coubesse e eternizasse sobre o olhar de todos, em qualquer lugar. (EVARISTO, 2003, p. 106-107, grifo nosso)

Passagem poética, o texto nos revela o lugar do negro na sociedade brasileira como indivíduo ainda sem voz, como mostra a expressão "autor desconhecido", e, ao lado, a consciência da possibilidade de possuir voz ativa, dando-se forma, em um desejo de "miniaturar a vida" por si mesmo, passando a ser "autor pelo próprio nome", escrevendo, para isto, as suas vivências. Desse modo, talvez, o encontrar-se e perder-se de Luandi, como se infere pelo fragmento acima, prefigura justamente isto que estamos analisando, isto é, para "achar-se" 
faz-se mister reconhecer o outro como irmão, em solidariedade, fazer o caminho de volta à memória comum, da coletividade, para que seja possível pensar um futuro único para todos estes ainda subalternos negros e negras do Brasil, que podem inscrever o nome na história revisitada e construída pelo grupo.

Nela, é a identidade e o reconhecimento que realmente importam, como se dá na observação emocionada de Luandi em relação à sua própria história familiar ao ver os objetos manuseados e criados pela mãe e pela irmã, não pelo proprietário, o Dr. Aristeu Pena Forte Soares Vicêncio, que carrega o sobrenome do Coronel Vicêncio, de que Luandi, porém, nunca ouviu falar, como fica claro na narrativa. Ana da Silva (2010) no artigo Da literatura negra à literatura feminina, afirma que:

Como arte da palavra, a literatura afro-feminina valoriza legados intelectuais e culturais africanos-brasileiros da tradição, saberes e práticas ancestrais de populações negras e desconstrói discursos poéticos e ficcionais que promovem seu recalque. [...] Os sujeitos poéticos e narradores, que compõe a literatura afro-feminina, por esse viés, se apresentam dispostos a buscarem, pela e com a palavra, o direito à voz. Esse exercício de poder pode ser compreendido como um ato de resistência peculiar às relações de poder e não como um subproduto. (SILVA, 2010, p. 101)

No mesmo estudo, a pesquisadora evoca Foucault (2002), utilizando o seguinte pensamento do filósofo francês: "Para resistir, é preciso que a resistência seja como o poder. Tão inventiva, tão móvel e produtiva quanto ele” (FOUCAULT, 2002, p. 241). Na esteira desta reflexão, concordamos com este argumento, entretanto, ressaltamos que o "poder" de nada adianta, caso seja exercido sozinho, como o Soldado Nestor, que prende, bate e pega pelo braço, à força, outros negros. Assim, é preciso ouvir a voz da velha ancestral Nêngua Kainda e olhar para os seus, para os chicotes apontados e fixos em direção aos irmãos. Em suma, alianças e solidariedades são claves para que o poder solitário não seja revestido em falsa liberdade. Para isto, metaforicamente, o fragmento do romance Ponciá Vicêncio, citado anteriormente, reclama e leva a interpretação para esta direção.

Então, sendo como "arte da palavra", como desenvolve Silva (2010) em relação à literatura negra afro-feminina, acreditamos que em Ponciá Vicêncio se prefigura esta vontade de dar forma a um discurso que "descontrói", termo utilizado pela pesquisadora, pretensões de manter pensamentos coloniais, mesmo em atitudes sem reflexão crítica de sujeitos subalternos, como Luandi, que desejava, como Nestor, exercer o poder na cidade, mandando, tendo "voz alta e forte como a dos brancos" (EVARISTO, 2003, p. 71, grifo nosso). Todavia, esta comparação já exerce e dá conta de toda a problemática quando um único negro consegue o "poder", quando sabemos que vários outros estão sendo empurrados para a morte, para a infelicidade, advinda de uma cruel e bárbara estrutura social, como fica claro na lembrança de Ponciá, quando esta tenta lembrar-se de algum caso de negro que tenha conseguido a "felicidade" na cidade: 
Outros não conseguiam trabalho ou ganhavam pouquíssimo e não tinham como viver. A vida se tornava pior do que na roça. Ela sabia de muitos casos tristes, em que tudo havia dado errado. Procurou se lembrar de algum que tivesse tido um final feliz. Não lembrou. (EVARISTO, 2003, p. 36)

Então, nesse lance de construir formas, como os vasos, utensílios e imagens criadas por estas personagens femininas com o barro retirado do rio, a ficção de Evaristo, como produto intelectual, artístico e de reflexão, é mola propulsora para pensarmos a possibilidade de voltarmos à memória ancestral como maneira de fazer "falar" a identidade comum, ligando-a, quem sabe, à contemporaneidade, para que possamos nos lembrar, com facilidade, de mais casos felizes na vida de diversos afrodescendentes do Brasil no futuro.

Para isso, é a ancestralidade que deve exercer um papel fundamental na aliança entres todos, como faz crer, simbolicamente, a imagem de Nêngua Kainda, mulher "ereta”, ancestral, antiga, sábia, atenta e ativa aos conselhos de quem pretende realizar o caminho de volta, como fez também o irmão de Ponciá, retornando à comunidade, à memória, à família: "Luandi fazia apressadamente o caminho de volta e nem sabia por quê. Não adiantava correr" (EVARISTO, 2003, p. 95).

No que tange à ancestralidade como forma de resistir aos discursos que tentam apagar a memória de tantos afrodescendentes, no texto, temos muitos exemplos, marcados, sobretudo por meio da religiosidade, crenças e costumes arraigados no cotidiano da comunidade negra, como vimos no início de nosso estudo - na crença da cobra celeste que bebe água do rio - mas também pode ser vislumbrado nos cantos, nas garrafadas, remédios de ervas, de Nêngua Kainda, etc. Ainda sob este aspecto, é fundamental traçarmos o itinerário feminino de Ponciá Vicêncio como vivência de "ressignificações", onde a memória encontra-se imbricada na trajetória junto dos seus.

Nesta situação, cansada com a vida de exploração da cidade, a personagem passa por um momento de angústia, desejando voltar ao barro e ao rio, este último como referência da religiosidade, marcada desde a infância, quando, esta viu, por exemplo, uma "mulher alta, muito alta que chegava até ao céu” (EVARISTO, 2003, p. 10). Dialogando com este aspecto, podemos afirmar que essa "visão" prefigura uma escritura feminina, assim como a vontade de estar próximo ao rio, lugar da ancestralidade, situando, portanto, a obra como textualidade marcada pelas vozes negras afro-femininas. Desse modo, a experiência com a religiosidade dá-se no campo da referência da imagem, poderíamos dizer, divina, representada pela "mulher alta", sendo, pois, lugar do "feminino". ${ }^{5}$ De acordo com Silva:

\footnotetext{
${ }^{5}$ No romance, há muitos exemplos que perfazem a narrativa como escritura afro-feminina. No que tange à questão levantada neste estudo, ou seja, a abordagem da forma da memória e da resistência negra, confirmamos, como camada mais complexa, a vivência de mulheres, pobres e negras, que, com todos os desafios colocados pela sociedade patriarcal e racista, no plano da narrativa, são as que dão melhor forma, metaforicamente, pelo barro, à memória coletiva. Cf. EVARISTO, 2003, p. 77: "Seria a que mais daria forma à massa seria a que mais criaria."
} 
A literatura afro-feminina, neste ínterim, pode ser considerada como um processo contínuo de (re) invenções de memórias, histórias e narrações sobre identidades, femininos e feminismos negros. Há nela um "retorno" dinâmico ao passado, ou seja, há um reconto de memórias ressignificadas, aliado a cenas de histórias, sonhos, vivências e resistências, no passado e no presente, vislumbrando cenas e agendas que gerem sonhos e conquistas no futuro. (SILVA, 2010, p. 100)

Do mesmo modo, neste entrecruzar com a memória ancestral, muitas vezes, revestida de religiosidade e sabedorias populares, a personagem Ponciá, pelo trabalho com o barro, juntamente com sua mãe, ressignifica, pela criatividade, formas de resistir ao apagamento de sua identidade. Neste ínterim, pela arte de modelar o barro, elas criam artefatos diversos, marcando a presença da família como partícipes da existência de toda uma comunidade, ligadas pela escravidão histórica de outrora. Na narrativa, vê-se que esta insistência em marcar a memória dos seus, coloca-se com ênfase na miniatura do avô, feito por Ponciá, mostrando-se presente em vários momentos do romance.

Neste sentido, compreendemos que as palavras, como o barro, só tem valor de verdadeira libertação para estes sujeitos, historicamente silenciados, quando são transformados em discurso "tecido" por si mesmos, ou seja, quando podem inscrever as suas vivências e pensamentos, desconstruindo, por sua vez, ideias estereotipadas, preconceituosas e configuradas na ideia do homem branco, sobretudo no caso das literaturas afro-femininas, em que se abrem questões mais complexas.

Dessa forma, voltar ao passado e à memória ancestral, significa falar para o presente, ressignificando modos de vida, assim como denunciando pensamentos excludentes e histórias colonizadoras, consideradas "verdadeiras" na visão dos não-subalternizados, imbuídas que são do desejo de marcar a superioridade. Então, nesses escritos ficcionais contemporâneos, ao contrário, o sujeito negro, mudo e caricato em tantos textos da literatura brasileira canônica, é convocado, simbolicamente, a "organizar novos quilombos, de inventar outra e nova vida" (EVARISTO, 2003, p. 84), em que a liberdade, de fato, não seja forjada, assim como navios negreiros e correntes não existam mais, como se fossem, pela magia de uma "varinha de condão" (EVARISTO, 2003, p. 48), transformados em camburões e algemas no Brasil de hoje.

\section{CoNSIDERAÇõES FINAIS}

Em nosso estudo, desenvolvemos uma abordagem pelas vias da análise do que chamamos forma da memória no romance Ponciá Vicêncio, de Conceição Evaristo. Trata-se de uma narrativa que compreende uma perspectiva contemporânea, implicando um aparecimento de sujeitos subalternos, pessoas que vivem nas margens da sociedade patriarcal e racista. Nosso intento, pois, foi pontuar na escritura, corpus deste trabalho, uma textualidade que marca uma 
ficção "afro-brasileira-feminina”. Assim, sublinhamos as passagens da narrativa que exemplificam questões que demonstram as relações entre o poder, a coletividade e a possibilidade da resistência quando sujeitos negros falam por si, inscrevendo a sua própria voz como "escrevivência”, no caso dos textos ficcionais, revestindo-se, por sua vez, de discurso contracolonial.

Em síntese, marcamos, neste trabalho, o valor da memória e da ancestralidade coletiva, como maneira de resistir ao apagamento da história de indivíduos negros, considerados subalternos. Para isto, é a criatividade da criatura, a exemplo da personagem feminina Ponciá Vicêncio, a qual é capaz de reverter contextos de subjugo, pois, na criação, está inscrita toda a identidade, o passado "iluminado" pelas mãos individuais da mulher que trabalha com o barro, dando-lhe forma, isto é, fazendo-o aparecer àqueles, que, por ventura, se esqueceram de fazer o caminho de volta à comunidade - ao quilombo - lugar ancestral e coletivo. Neste clã, pode-se pensar, simbolicamente, em alianças, para, enfim, marcar solidariedades com o fim de denunciar contextos de exclusão racista.

\section{REFERÊNCIAS}

BAROSSI, Luana. (Po)éticas da escrevivência. Estudos de literatura brasileira contemporânea, Brasília, n. 51, p. 22-40, mai.-ago., 2017.

EVARISTO, Conceição. Ponciá Vicêncio. Belo Horizonte: Mazza Edições, 2003.

EVARISTO, Conceição. Literatura negra: uma poética de nossa afro-brasilidade. Scripta, Belo Horizonte, v. 13, n. 25, p. 17-31, 2. sem., 2009.

FOUCAULT, Michel. Microfísica do poder. 17. ed. Trad. Roberto Machado. Rio de Janeiro: Graal, 2002.

FOUCAULT, Michel. História da sexualidade I: A vontade de saber. 13. ed. Trad. Maria Thereza da Costa Albuquerque e J. A. Guilhon Albuquerque. Rio de Janeiro: Graal, 1999.

OLIVEIRA, Natalino da Silva de. "Escrever é sangrar": reflexões sobre a ancestralidade, racismo e dor em Olhos d'água de Conceição Evaristo. Aletria. Belo Horizonte, v. 29, n. 1, p. 179-195, 2019.

PEREIRA, Rodrigo da Rosa. A periferia em Conceição Evaristo e Esmeralda Ribeiro: questões de gênero, raça e classe. Estudos de literatura brasileira contemporânea. Brasília, n. 49, p. 33-50, set./dez., 2016.

SCHØLLHAMMER, Karl Erik. Ficção brasileira contemporânea. Rio de Janeiro: Civilização Brasileira, 2009.

SILVA, Ana Rita Santiago da. Da literatura negra à literatura afro-feminina. Via Atlântica, São Paulo, n. 18, p. 91-102, 2010. 
SPIVAK, Gayatri Chakravorty. Pode o subalterno falar? Trad. Sandra Regina Goulart Almeida, Marcos Pereira Feitosa e André Pereira Feitosa. Belo Horizonte: Ed. UFMG, 2010.

Recebido para publicação em: 1 maio 2021. Aceito para publicação em: 25 nov. 2021. 